\title{
Belowground DNA-based techniques: untangling the network of plant root interactions
}

\author{
Liesje Mommer • Alex J. Dumbrell • \\ C. (Niels) A. M. Wagemaker • N. Joop Ouborg
}

Received: 13 June 2011 / Accepted: 12 August 2011 / Published online: 20 September 2011

C The Author(s) 2011. This article is published with open access at Springerlink.com

\section{Introduction}

Plant roots are a central driver of ecosystem productivity, as plant investments belowground often comprise more than half of total plant biomass (Jackson et al. 1996). Despite this general observation, almost nothing is known about the distribution of roots in ecosystems; generally because roots of different species are morphologically indistinguishable, restricting species identification. This is in strict contrast to plant identification aboveground, which is straightforward after initial taxonomic training.

Responsible Editor: Hans Lambers.

\section{Mommer $(\bowtie)$}

Nature Conservation and Plant Ecology,

Wageningen University,

PO Box 47, 6700 AA Wageningen, The Netherlands

e-mail: Liesje.Mommer@wur.nl

\section{Mommer}

Experimental Plant Ecology, Institute for Water and Wetland Research, Radboud University Nijmegen,

PO Box 9010, 6500 GL Nijmegen, The Netherlands

\author{
A. J. Dumbrell \\ Department of Biological Sciences, University of Essex, \\ Wivenhoe Park, \\ Colchester CO4 3SQ, UK \\ C. (N.) A. M. Wagemaker · N. J. Ouborg \\ Molecular Ecology, Institute for Water and Wetland \\ Research, Radboud University Nijmegen, \\ PO Box 9010, 6500 GL Nijmegen, The Netherlands
}

Although in species poor systems containing roots of two species morphological identification has been possible in a few cases (Genney et al. 2002; Janecek et al. 2004; Mommer et al. 2011), disentangling and identifying roots from species-rich systems is impossible. To overcome problems of species identification, pioneering DNA-based techniques have been applied to plant roots (Jackson et al. 1999; Linder et al. 2000) and are now being used in experimental and observational studies of species-rich plant communities (e.g. Mommer et al. 2010; Kesanakurti et al. 2011; Dumbrell et al. 2011). In this paper, we discuss the current state of molecular techniques for plant species identification and quantification from mixed root samples. We focus on crucial aspects in the methodology regarding primer choice, DNA extraction and PCR inhibition, showing the potential caveats and their solutions. Finally we briefly discuss a few questions in the field of root ecology that will be advanced significantly by the appropriate use of these molecular tools.

\section{Developing methodological tools for root ecology}

Untangling species identity and abundance of plant roots has received considerable methodological attention over the last few years. Different approaches making use of biochemical to molecular advances have been followed. The basis of biochemical techniques is the difference in species specific 
chemical composition of roots. The use of Near Infrared Reflectance Spectroscopy (NIRS) on milled mixed root samples shows species identity and quantity (Roumet et al. 2006). Alternatively, the differential composition of plant waxes can also be used to differentiate among species, as alkane and alcohol composition are species and tissue specific (Dawson et al. 2000). These biochemical methods provide accurate estimates of species identity and abundance in mixed root samples. However, different environmental conditions change the chemical properties of plant tissues (e.g. atmospheric $\mathrm{CO}_{2}$ conditions, Soussana et al. 2005 or herbivory, Dawson et al. 2000) which makes the application of these methods more useful in controlled mesocosm experiments with a limited variability in soil chemistry, plant age and plant species richness compared with complex and diverse natural fields.

Molecular methods, based on genomic differences among species do not have these limitations. Jackson et al. (1999) and Linder et al. (2000) pioneered the use of DNA based techniques for indentifying plant roots. They selected many different single root fragments from trees, extracted DNA from each fragment separately and determined species identity using species-specific regions of the DNA (i.e. internal transcribed spacer (ITS)) and compare that to a reference database. Follow up studies used similar approaches to determine species identity using different loci (see references below). Using this qualitative approach to estimate relative species proportion in mixed root samples would require analysis of a very large number of small root parts from one mixed sample. Therefore, Mommer et al. (2008) developed an alternative approach to quantify relative species abundances in mixed root samples via quantitative real-time PCR on species-specific markers. In order to translate the relative abundance to root biomass, relative DNA abundances in species are calibrated against an accurate multi-species reference series.

At the moment, the era of next generation sequencing is in full swing and it is now potentially possible to generate more data from plant roots than can ever be analysed. Thus, it is crucial to focus research and insure a balance between ecological question and methodology. This commentary gives a glimpse of the molecular methodological issues that are topical at the moment.

\section{Primer types: species- specific or universal markers?}

Primer choice is a fundamental issue in molecular ecology and thus essential when undertaking molecular analyses of mixed root samples. The choice of primer largely determines which of the two main approaches are used (e.g. quantitative real time-PCR (qPCR) or large scale sequencing). The first option is to use and/or develop species-specific primer sets, which is initially time consuming in terms of finding optimal primers. Generally, ITS (e.g. Haling et al. 2011) or ISSR (Mommer et al. 2008) regions of the DNA of the different study species are amplified, sequenced, and tested for species specificity against reference sequence databases, to identify speciesspecific primer sets. However, new genomes are increasingly being submitted to sequence repositories (e.g. GenBank, NCBI) and finding species-specific primers will no doubt become easier and quicker. Once developed, species-specific primer sets produce robust and consistent (semi) quantitative speciesabundance data, via qPCR (McNickle et al. 2008; Mommer et al. 2010; Haling et al. 2011).

The second option is to use universal DNAbarcode primers targeting plastid genes (Taberlet et al. 2007; Hollingsworth et al. 2009) combined with second generation sequencing techniques (e.g. Roche 454) for data generation. A large scale plant barcoding study concluded that $m a t \mathrm{~K}$ and $r b c \mathrm{~L}$ are the most promising markers, based on assessments of recoverability, sequence quality and species discrimination (Hollingsworth et al. 2009). For example, 1000 tropical orchid species could be identified using the matK DNA barcode (Lahaye et al. 2008). rbcL was used in a study of root diversity in grasslands (Kesanakurti et al. 2011), but appeared to have insufficient power to discriminate between roots of tree species from Barro Colorado Island, Panama (Jones et al. 2011). Jones et al. (2011), therefore, used trn $\mathrm{H}-p s b \mathrm{~A}$ to discriminate between 33 species from 117 root fragments. However, in recent root studies, an alternative, and often less species specific, barcode $(\operatorname{trn} \mathrm{L})$ is more frequently used (Brunner et al. 2001; Ridgway et al. 2003; Frank et al. 2010; Dumbrell et al. 2010; Taggart et al. 2011). This variety in the usage of different barcode primers reflects that primer choices will always need to be adjusted to the molecular differentiation found across species within 
a particular community or experimental system. At an even finer molecular resolution, primer sets have also been successfully designed to discriminate among roots of different individuals of the same species. For example, Saari et al. (2005) and Lang et al. (2010) have used microsatellite primers to distinguish between individuals of the same tree species.

\section{Species recovery belowground: issues of primer specificity, DNA extraction, PCR inhibition}

A problem with DNA barcoding studies on roots is that species recovery belowground appears suboptimal, as several plant species recorded aboveground and rooting in sampled locations, are not detected. Subsequently, studies fail to detect $\approx 15-30 \%$ of aboveground species belowground (Taggart et al. 2011; Kesanakurti et al. 2011) and significantly underestimate biodiversity. Yet reasons for this underestimation of species richness remain poorly investigated, but below we discuss three potential caveats and solutions. A general recommendation beforehand to increase species recovery would be to investigate if the problems are due to the root tissue or are speciesspecific by analyzing additional aboveground samples, against which belowground sequences can be compared and validated.

A initial problem with species detection may reflect the ability of the barcode region to differentiate between closely related species and/or the specificity of barcode primers. The inability of DNA barcodes to separate closely related plant species is a common problem. Although barcode genes tend to have highly conserved priming regions, many of them (e.g. $\operatorname{trn} \mathrm{L}$ intron) have similar sequences across species within a genus (see Taberlet et al. 2007), leading to the detection of 'species groups'. Improvements in barcode resolution have proven difficult, for example increasing the number of plastid loci to 3 did not or hardly increased species recovery (Fazekas et al. 2009; Taggart et al. 2011), but as aforementioned primer sets should be intensively tested and adjusted to the experimental system.

A second explanation for the apparent absence of species belowground when already recorded aboveground, can be low quality DNA in root samples. Kesanakurti et al. (2011) showed that $16 \%$ of 1531 DNA extracts were of insufficient quality for se- quencing, which is a considerable amount. Therefore, knowledge of DNA degradation in roots from natural communities is essential. Riley et al. (2010) showed that DNA yield from dead roots of common pasture plants declined within a few days, even when originally grown in controlled conditions. It is unknown if DNA from some species degrades faster than that of other species, but this could potentially occur. Haling et al. (2011) also investigated the effect on DNA yield of storing root samples, but storage at $4^{\circ} \mathrm{C}$ for a few days did not decrease the DNA yield in the species tested. However, storage at $20^{\circ} \mathrm{C}$ did significantly decrease DNA yield (Bainard et al. 2010; Riley et al. 2010).

Other than careful preservation of samples before DNA extraction, another option for increasing DNA yield is to examine new techniques in DNA extraction. For example, work on ancient plant DNA is beginning to provide protocols and commercially available kits specifically designed for degraded and/ or old woody root tissues (see Parducci and Petit 2004; Gugerli et al. 2005; Finkeldey et al. 2010). In addition, other methods have been implemented for plant tissue with high polysaccharide levels that may inhibit DNA isolation (Shepherd and McLay 2011). A factor known to decrease DNA extraction is plant age, or more specifically tissue age. DNA yield appeared lower from older plants (Haling et al. 2011) and old woody roots (Finkeldey et al. 2010), as DNA degradation is a controlled cellular process during cell death. In such cases the use of primers that amplify short fragments is recommended (see Sønstebø et al. 2010).

A third limiting and potentially important factor for species identification in roots can be PCR inhibition. Roots and leaves potentially differ in the type of inhibitors that are at work. PCR inhibition in roots often comes from attached humic acids that are present in the soil. Humic acid binds to $\mathrm{MgCl}_{2}$ and inhibits PCR. PCR inhibitors from leaves may come from complex polysaccharides found in the plant tissue. As the more general plant DNA extraction kits are good at removing plant-based inhibitors (e.g. some polysaccharides) but are often not designed for soil, generally more of the soil based inhibitors will remain in final samples. Various methods for removing soil based PCR inhibitors and exist, for example via the addition of proteins that bind to humic acids (Tebbe and Vahjen 1993). 
The degree of PCR inhibition can easily be tested by adding an internal DNA standard to the actual DNA extracts. Haling et al. (2011) showed the value of such an approach. If an internal standard (e.g. a known quantity of ground lucerne seeds) was added to the root samples, a strongly significant linear correlation between root biomass and species abundance (based on species-specific quantitative PCR primers) was observed for each of their study species (Haling et al. 2011). By adding this internal standard, they even challenged the most time-consuming part of root research: washing plant roots. Haling et al. (2011) extracted root DNA directly from soil cores and used (qPCR) for further analyses. Interestingly, adding an internal standard to washed root samples from any system (experimental or field) will lead to stronger correlations between root biomass and DNA yield via qPCR estimates, resulting in fully rather than semi quantitative data of roots in mixed samples.

\section{Roots: living or dead?}

In the grasslands studied by Kesanakurti et al. (2011), 39 species were observed aboveground, but 10 of these were not recovered belowground. Interestingly, also 10 'new' species were found that were not observed in the aboveground samples. This discovery of new species can be explained by sampling error, incomplete aboveground identification or may be due to the fact that species may have been dormant belowground. Another explanation might be that species recovery in DNA extracts of roots may reflect both current and historic species, as it has always been difficult to separate dead roots from living ones. To illustrate this point, Sønstebø et al. (2010) showed that in 15-thousand-year-old permafrost samples up to 47 molecular taxonomic units could be identified. Thus, to disentangle live and dead roots we require methods that screen for biologically active roots. One possibility could be to extract total RNA from samples, and screen for the activity of commonly studied household genes, using species specific qPCR primers.

\section{Exploring bare ground}

After these methodological issues raised above have been carefully solved, the way is open for answering key questions in root ecology. One of the longstanding hypotheses that can finally be investigated is if the observed positive relationship between primary production and plant species richness (Hooper et al. 2005) is driven by spatial niche differentiation through differences in rooting distribution (Berendse 1983; Mamolos et al. 1995; Parrish and Bazzaz 1976). Roots of different species may occupy different realized niches. When several species are growing in mixtures the community is expected to explore a broader niche space (i.e. soil volume) and produce more biomass than each of the species separately (Berendse 1983; Fargione and Tilman 2005; Levine and HilleRisLambers 2009). Until recently, no information on the root distributions was available that allowed for testing the spatial niche differentiation hypothesis. The application of molecular markers in a biodiversity experiment showed that root distributions of four grassland species were less different than expected, giving only slight support for niche differentiation (Mommer et al. 2010). However, mixtures produced $40 \%$ more biomass belowground than expected as observed more often from grasslands (Tilman et al. 2001; Dimitrakopoulos and Schmid 2004; Reich et al. 2004); and forests (Brassard et al. 2011), suggesting that species-specific below ground interactions are driving the biodiversity-productivity relationship.

Another topic that will benefit from the applying molecular techniques is the horizontal distribution of roots. The question of: if and under which conditions plant roots are territorial? is still inconclusively answered (Schenk et al. 1999). Caldwell and coworkers observed segregated root systems of shrubs and grasses around cold desert shrubs (Caldwell et al. 1991). However, in other environments contrasting results are found. Root distributions of beech (Fagus sylvatica) individuals in monoculture stands did not indicate root segregation (Lang et al. 2010). Results of Jones et al. (2011) also suggest that roots in hyperdiverse tropical forests appear to overlap more belowground than do their crowns aboveground, suggesting intense root aggregation. The spatial extent to which belowground plant-plant interactions occur, and how these differ from the aboveground scales occur will be revealed in the coming years, using state of the art DNA techniques.

Root growth is mainly driven by nutrient and water availability, but numerous chemical substances (Bais et 
al. 2006) and soil biota (bacteria, fungi, nematodes) (Kardol et al. 2007; Raaijmakers et al. 2009; Bever et al. 2010) are also known to moderate root growth. Since the composition of the rhizosphere community may be driven largely by plant species identity (Bezemer et al. 2010), it is highly likely that interspecific root interactions act partly via these soil organisms. DNA-based investigations of root abundance yield as a 'bonus', information about soil biota, such as arbuscular mycorrhizal (AM) fungi and fungal pathogens that are attached to the plant roots. For example, by using plant DNA barcodes, Dumbrell et al. (2010) showed that the composition and structure of plant-associated AM fungal communities was primarily determined by the local soil environment and not the identity of the hostplant species. However, this is unlikely to be true for the majority of rhizosphere biota, where the species identity of the host-plant is likely to play a major role. Only the application of DNA based techniques allows this to be fully examined in natural systems. The new DNA based methods, currently developed to identify and quantify belowground plant structures in diverse soils will unveil the interactions among plant roots and their soil biota.

Acknowledgements LM is supported by supported by the Netherlands Organization for Scientific Research (NWO) with VENI grant 016091116.

Open Access This article is distributed under the terms of the Creative Commons Attribution Noncommercial License which permits any noncommercial use, distribution, and reproduction in any medium, provided the original author(s) and source are credited.

\section{References}

Bainard LD, Klironomos JN, Hart MM (2010) Differential effect of sample preservation methods on plant and arbuscular mycorrhizal fungal DNA. J Microbiol Meth 82:124-130

Bais HP, Weir TL, Perry LG, Gilroy S, Vivanco JM (2006) The role of root exudates in rhizosphere interactions with plants and other organisms. Annu Rev Plant Biol 57:233-266

Berendse F (1983) Interspecific competition and niche differentiation between Plantago lanceolata and Anthoxanthum odoratum in a natural hayfield. J Ecol 71:379-390

Bever JD, Dickie IA, Facelli E, Facelli JM, Klironomos J, Moora M, Rillig MC, Stock WD, Tibbett M, Zobel M (2010) Rooting theories of plant community ecology in microbial interactions. Trends Ecol Evol 25:468-478

Bezemer TM, Fountain MT, Barea JM, Christensen S, Dekker SC, Duyts H, van Hal R, Harvey JA, Hedlund K, Maraun
M, Mikola J, Mladenov AG, Robin C, de Ruiter PC, Scheu S, Setala H, Smilauer P, van der Putten WH (2010) Divergent composition but similar function of soil food webs of individual plants: plant species and community effects. Ecology 91:3027-3036

Brassard BW, Chen HYH, Bergeron Y, Pare D (2011) Differences in fine root productivity between mixed- and singlespecies stands. Funct Ecol 25:238-246

Brunner I, Brodbeck S, Büchler U, Sperisen C (2001) Molecular identification of fine roots of trees from the Alps: reliable and fast DNA extraction and PCR-RFLP analyses of plastid DNA. Mol Ecol 10:2079-2087

Caldwell MM, Manwaring JH, Durham SL (1991) The microscale distribution of neighbouring plant roots in fertile soil microsites. Funct Ecol 5:765-772

Dawson LA, Mayes RW, Elston DA, Smart TS (2000) Root hydrocarbons as potential markers for determining species composition. Plant Cell Environ 23:743-750

Dimitrakopoulos PG, Schmid B (2004) Biodiversity effects increase linearly with biotope space. Ecol Lett 7:574-583

Dumbrell AJ, Nelson M, Helgason T, Dytham C, Fitter AH (2010) Relative roles of niche and neutral processes in structuring a soil microbial community. ISME J 4:337345

Dumbrell AJ, Ashton PD, Aziz N, Feng G, Nelson M, Dytham C, Fitter AH, Helgason T (2011) Distinct seasonal assemblages of arbuscular mycorrhizal fungi revealed by massively parallel pyrosequencing. New Phytologist 190:794-804

Fargione J, Tilman D (2005) Niche differences in phenology and rooting depth promote coexistence with a dominant C4 bunchgrass. Oecologia 143:598-606

Fazekas AJ, Kesanakurti PR, Burgess KS, Percy DM, Graham SW, Barrett SCH, Newmaster SG, Hajibabaei M, Husband BC (2009) Are plant species inherently harder to discriminate than animal species using DNA barcoding markers? Mol Ecol Resour 9:130-139

Finkeldey R, Leinemann L, Gailing O (2010) Molecular genetic tools to infer the origin of forest plants and wood. Appl Microbiol Biotechnol 85:1251-1258

Frank DA, Pontes AW, Maine EM, Caruana J, Raina R, Raina S, Fridley JD (2010) Grassland root communities: species distributions and how they are linked to aboveground abundance. Ecology 91:3201-3209

Genney DR, Alexander IJ, Hartley SE (2002) Soil organic matter distribution and below-ground competition between Calluna vulgaris and Nardus stricta. Funct Ecol 16:664670

Gugerli F, Parducci L, Petit RJ (2005) Ancient plant DNA: review and prospects. New Phytologist 166:409-418

Haling RE, Simpson RJ, McKay AC, Hartley D, Lambers H, Ophel-Keller, K, Wiebkin S, Herdina H, Riley IT, Richardson AE (2011) Direct measurement of roots in soil for single and mixed species using a quantitative DNA-based method. Plant Soil. doi:10.1007/s11104-011-0846-3

Hollingsworth PM, Forrest LL, Spouge JL, Hajibabaei M, Ratnasingham S, van der Bank M, Chase MW, Cowan RS, Erickson DL, Fazekas AJ, Graham SW, James KE, Kim KJ, Kress WJ, Schneider H, van AlphenStahl J, Barrett $\mathrm{SCH}$, van den Berg C, Bogarin D, Burgess KS, Cameron KM, Carine M, Chacon J, Clark A, Clarkson JJ, Conrad F, 
Devey DS, Ford CS, Hedderson TAJ, Hollingsworth ML, Husband BC, Kelly LJ, Kesanakurti PR, Kim JS, Kim YD, Lahaye R, Lee HL, Long DG, Madrinan S, Maurin O, Meusnier I, Newmaster SG, Park CW, Percy DM, Petersen G, Richardson JE, Salazar GA, Savolainen V, Seberg O, Wilkinson MJ, Yi DK, Little DP, Grp CPW (2009) A DNA barcode for land plants. Proc Natl Acad Sci USA 106:12794-12797

Hooper DU, Chapin FS, Ewel JJ, Hector A, Inchausti P, Lavorel S, Lawton JH, Lodge DM, Loreau M, Naeem S, Schmid B, Setala H, Symstad AJ, Vandermeer J, Wardle DA (2005) Effects of biodiversity on ecosystem functioning: a consensus of current knowledge. Ecol Monogr 75:3-35

Jackson RB, Canadell J, Ehleringer JR, Mooney HA, Sala OE, Schulze ED (1996) A global analysis of root distributions for terrestrial biomes. Oecologia 108:389-411

Jackson RB, Moore LA, Hoffmann WA, Pockman WT, Linder CR (1999) Ecosystem rooting depth determined with caves and DNA. Proc Natl Acad Sci USA 96:1138711392

Janecek S, Janeckova P, Leps J (2004) Influence of soil heterogeneity and competition on growth features of three meadow species. Flora 199:3-11

Jones FA, Erickson DL, Bernal MA, Bermingham E, Kress WJ, Allen Herre E, H.C. M-L, Turner BL (2011) The roots of diversity: belowground richness and rooting distributions in a tropical forest revealed by DNA barcodes and inverse modelling. Plos One, in press

Kardol P, Cornips NJ, van Kempen MML, Bakx-Schotman JMT, Van der Putten WH (2007) Microbe-mediated plantsoil feedback causes historical contingency effects in plant community assembly. Ecol Monogr 77:147-162

Kesanakurti PR, Fazekas AJ, Burgess KS, Percy DM, Newmaster SG, Graham SW, Barrett SCH, Hajibabaei M, Husband BC (2011) Spatial patterns of plant diversity below-ground as revealed by DNA barcoding. Mol Ecol 20:1289-1302

Lahaye R, Van der Bank M, Bogarin D, Warner J, Pupulin F, Gigot G, Maurin O, Duthoit S, Barraclough TG, Savolainen V (2008) DNA barcoding the floras of biodiversity hotspots. Proc Natl Acad Sci USA 105:2923-2928

Lang C, Dolynska A, Finkeldey R, Polle A (2010) Are beech (Fagus sylvatica) roots territorial? For Ecol Manag 260:1212-1217

Levine JM, HilleRisLambers J (2009) The importance of niches for the maintenance of species diversity. Nature 461:254257

Linder CR, Moore LA, Jackson RB (2000) A universal molecular method for identifying underground plant parts to species. Mol Ecol 9:1549-1559

Mamolos AP, Elisseou GK, Veresoglou DS (1995) Depth of root activity of coexisting grassland species in relation to $\mathrm{N}$ and $\mathrm{P}$ additions, measured using nonradioactive tracers. J Ecol 83:643-652

McNickle GG, Cahill JF, Deyholos MK (2008) A PCR-based method for the identification of the roots of 10 cooccurring grassland species in mesocosm experiments. Botany-Botanique 86:485-490

Mommer L, Wagemaker N, de Kroon H, Ouborg NJ (2008) Unravelling belowground plant distributions: a real time
PCR method for quantifying species proportions in mixed root samples. Mol Ecol Notes 8:947-953

Mommer L, van Ruijven J, de Caluwe H, Smit-Tiekstra AE, Wagemaker CAM, Ouborg NJ, Bogemann GM, van der Weerden GM, Berendse F, de Kroon H (2010) Unveiling below-ground species abundance in a biodiversity experiment: a test of vertical niche differentiation among grassland species. J Ecol 98:1117-1127

Mommer L, Van Ruijven J, Jansen C, Van de Steeg HM, De Kroon H (2011) Interactive effects of nutrient heterogeneity and competition: implications for root foraging theory. Functional Ecology; in press

Parducci L, Petit RJ (2004) Ancient DNA - unlocking plants' fossil secrets. New Phytologist 161:335-339

Parrish JAD, Bazzaz FA (1976) Underground niche separation in successional plants. Ecology 57:1281-1288

Raaijmakers JM, Paulitz TC, Steinberg C, Alabouvette C, Moënne-Loccoz Y (2009) The rhizosphere: a playground and battlefield for soilborne pathogens and beneficial microorganisms. Plant and Soil. doi:10.1007/s11104-0089568-6

Reich PB, Tilman D, Naeem S, Ellsworth DS, Knops J, Craine J, Wedin D, Trost J (2004) Species and functional group diversity independently influence biomass accumulation and its response to $\mathrm{CO} 2$ and N. Proc Natl Acad Sci USA 101:10101-10106

Ridgway K, Duck J, Young JP (2003) Identification of roots from grass swards using PCR-RFLP and FFLP of the plastid trnL (UAA) intron. BMC Ecol 3:8

Riley IT, Wiebkin S, Hartley D, McKay AC (2010) Quantification of roots and seeds in soil with real-time PCR. Plant and Soil 331:151-163

Roumet C, Picon-Cochard C, Dawson LA, Joffre R, Mayes R, Blanchard A, Brewer MJ (2006) Quantifying species composition in root mixtures using two methods: nearinfrared reflectance spectroscopy and plant wax markers. New Phytologist 170:631-638

Saari SK, Campbell CD, Russell J, Alexander IJ, Anderson IC (2005) Pine microsatelite markers allow roots and ectomycorrhizas to be linked to individual trees. New Phytologist 165:295-304

Schenk HJ, Callaway RM, Mahall BE (1999) Spatial root segregation: are plants territorial? Adv Ecol Res 28:145180

Shepherd LD, McLay TGB (2011) Two micro-scale protocols for the isolation of DNA from polysaccharide-rich plant tissue. J Plant Res 124:311-314

Sønstebø JH, Gielly L, Brysting AK, Elven R, Edwards M, Haile J, Willerslev E, Coissac E, Rioux D, Sannier J, Taberlet P, Brochmann C (2010) Using next-generation sequencing for molecular reconstruction of past Arctic vegetation and climate. Mol Ecol Resour 10:10091018

Soussana JF, Teyssonneyre F, Picon-Cochard C, Dawson L (2005) A trade-off between nitrogen uptake and use increases responsiveness to elevated $\mathrm{CO} 2$ in infrequently cut mixed C-3 grasses. New Phytologist 166:217-230

Taberlet P, Coissac E, Pompanon F, Gielly L, Miquel C, Valentini A, Vermat T, Corthier G, Brochmann C, Willerslev E (2007) Power and limitations of the chloro- 
plast trnL (UAA) intron for plant DNA barcoding. Nucleic Acids Res 35

Taggart JM, Cahill JF, McNickle GG, Hall JC (2011) Molecular identification of roots from a grassland community using size differences in fluorescently labelled PCR amplicons of three cpDNA regions. Mol Ecol Resour 11:185-195
Tebbe CC, Vahjen W (1993) Interference of humic acids and dna extracted directly from soil in detection and transformation of recombinant-dna from bacteria and a yeast. Appl Environ Microbiol 59:2657-2665

Tilman D, Reich PB, Knops J, Wedin D, Mielke T, Lehman C (2001) Diversity and productivity in a long-term grassland experiment. Science 294:843-845 